\title{
Going beyond the 'library': the current work of the Scottish Information Literacy Project
}

John Crawford, Christine Irving

\begin{abstract}
Reviews briefly the origins of the Scottish Information Literacy Project from its origins in 2004 as a project solely devoted to developing a National Information Literacy Framework for Scotland to the present time. The project now encompasses workplace information literacy, the skills agenda, lifelong learning and media literacy. The article concentrates on current activity: the restructuring of the first draft of the Framework to make it a genuine lifelong learning document and the pursuit of the workplace agenda, following a successful research project. This now focuses strongly on having information literacy recognised as an essential workplace skill. Work is also being undertaken with public library partners to develop information literacy training in public libraries. The policy implications of the work are reviewed.
\end{abstract}

What is now the Scottish Information Literacy Project (rebranded as such in 2007) grew out of a community engagement project with a school in a deprived area of Glasgow (McLelland and Crawford, 2004) which took place in 2003. Although very much a seed corn exploratory project it generated a major research agenda, including areas still to be explored such as the role of information in supporting asylum seekers. The principal finding was the need to develop an information literacy framework linking secondary and tertiary education. This led to what was initially expected to be a one year project whose sole aim was to devise a draft (Scottish) National Information Literacy Framework and Christine Irving was employed in October 2004 to undertake this work.

\section{John Crawford}

John Crawford is Library Research Officer and Director, Scottish Information Literacy Project.

Email: jer@gcal.ac.uk

\section{Christine Irving}

Christine Irving is Project Officer, Scottish Information Literacy Project. 
This sole objective did not last long. We soon discovered a need to explain and promote the concept of information literacy to educational and other bodies which we either wanted to influence or seek funding from. This led directly to a petition to the Scottish Parliament. Signatures were collected from all over the world, not just from Scotland and we were invited to present the petition in person to the Petitions Committee. We therefore had to develop an advocacy focus. When the project started we quickly recruited leading information literacy advocates in secondary and higher education in Scotland as Project partners. This has given the Project a strong partnership focus and we have now moved on from education to recruit partners in the workplace, public libraries, the skills and the Adult Literacies agendas.

The Project has therefore now expanded to include the following objectives with an increasing focus on lifelong learning/skills and workplace issues:

- To develop an information literacy framework, linking primary, secondary and tertiary education to lifelong learning including workplace and adult literacies agendas

- Advocacy on behalf of information literacy for education and the wider community

- Working with information literacy champions both UK and worldwide

- Researching and promoting information literacy in the workplace

- Identifying and working with partners, both in education and the wider community

- Researching the role of information literacy in continuing professional development

- Researching the health literacies agenda

Some background to the project may be found in Crawford and Irving (2007).

The Project is now a mature and experienced one but the difficulties it faces are as considerable as the opportunities. It consists of John Crawford as Project Director and Christine Irving as Project Officer. While John's salary is internally funded, Christine's salary is entirely externally funded. Obtaining appropriate funding has been a constant and time consuming battle. We are grateful for the support we have received from such varied bodies as the former learndirect Scotland, Eduserv, Learning and Teaching Scotland, the British Academy and the Esmee Fairbairn Foundation. The fact that we have no received no funding at all from LIS bodies is worthy of comment, as is the difficulty of raising funding for a project which operates at the intersection of LIS research, educational development and new skills promotion, not to mention the lifelong learning and civil rights in information issues.

However, recognition has not proved to be a problem. Invitations to present at conferences about our work have been continuous since the early days of the Project including keynote presentations to the LILAC and School Library Association UK conferences in 2008. We have held two successful open meetings about the project which have attracted attendees from all over the British Isles. 
Nor has international recognition been a problem. A visit to Washington by John in October 2007 to address a meeting of the US National Forum on Information Literacy raised the Project profile and drew attention to the health and media literacies agenda (Crawford, 2008). In December 2007 we received a visit from a delegation of Finnish librarians who had identified us as one of three centres of information literacy activity in the UK which they wished to find out about (Stubbings, 2008). In June 2008 we hosted a visit organised by the University of Wisconsin, Whitewater for twelve school librarians and seven teachers, all engaged in professional development to whom we gave a presentation on our work. Our work on information in the workplace and the schools sector has attracted the attention of colleagues at the Charles Sturt University in Australia and we hope to work together in areas of common interest.

In our current funding round, overview details of which can be found at Crawford and Irving (2008a) which ends in September 2009 we are concentrating on two main areas within our overall objectives:

- To develop the Framework to extend the early years, workplace, wider access and lifelong learning components to make it a genuine lifelong learning document

- To research and progress the information literacy in the workplace agenda

\section{The Framework}

To develop the framework, other frameworks, models and definitions at home and abroad were examined. The aim was to map the existing learning that was taking place and allocate a notional level to learning outcomes utilising relevant reference points such as the SCQF (Scottish Credit and Qualifications Framework) generic level descriptors. The intention of this was to provide a general shared understanding of each level which can then be linked to academic, vocational or professional practice. The starting point for developing the framework was SCQF level 5 (Intermediate 2) as the only current national SQA (Scottish Qualifications Authority) Information Literacy Skills (formerly Information Handling Skills) qualification which is at this level. This was then used as a template for drawing up equivalent SCQF levels 4 to 1 and 6 to 7 covering secondary schools and further education colleges. Higher education and further education colleges cover SCQF levels 8 to 12. Higher Education (HE) uses the SCONUL model, therefore it was felt that the skills within the seven headline skills from the SCONUL Seven Pillars Model for Information Literacy should be used. In addition, exemplars of how two universities have adopted and modified this model to create IL frameworks for their own institutions were added to the framework appendices. The SCQF levels do not cover primary schools but there is good practice in this area covering the 5-14 curriculum within Scotland (currently being replaced by the new Curriculum for Excellence 3-18 (CfE, 2008), and the City of Edinburgh's Explore model was used. A short section on lifelong learning including workplace learning was also included. 
The Framework was completed by spring 2007 and piloted between September 2007 and Easter 2008. Partners were contacted regarding the piloting activities we were looking for:

- Students/pupils within a particular subject area

- A year group

- A particular cohort of students/pupils within a subject area

- Transition from primary to secondary, secondary to FE or HE, FE to HE

- Exemplars of good practice from any of the above

- Alternatively to test the framework against their own institutions' Learning and Teaching polices and practices or independent learning strategy.

Meetings / visits / presentations were arranged to discuss the framework and piloting of the framework with partners and interested parties and to hear about / see partner information literacy activities both current and planned. The piloting included the identification of good practice, some of which were showcased at the Project Open Meeting at the end of May 2008 by project partners Craigholme School, Ardrossan Academy, the University of Abertay and the Scottish Government Information Management Unit (Information and Library Services).

The Framework is also beginning to achieve formal recognition. In February 2008 the Curriculum for Excellence Literacy and Language draft outcomes and experiences were published. Of particular importance to the project are the three lines of development for literacy skills:

- Reading - Enjoyment and Choice, Tools for reading, Finding and using information, Understanding, analysing and evaluating

- Writing - Enjoyment and Choice, Tools for writing, organising and using information, creating texts

- Listening and talking - Enjoyment and Choice, Tools for listening and talking, Finding and using information, Understanding, analysing and evaluating, creating texts

These development lines reflect information literacy skills and competencies contained within the framework.

The work on the Framework has been usefully supported by an award of funding in Spring 2008 by Learning and Teaching Scotland (LTS) to develop exemplars of good practice in information literacy activities in Scottish schools. These are to be mounted on the LTS CfE Sharing practice website so they can be used by teachers and school librarians. This has produced 10 case studies: North Ayrshire Toolkit; Ardrossan Academy Information Literacy skills work; Caldervale High English \& Computing; Abronhill High Information Literacy programme; City of Edinburgh ExPLORE Model; James Gillespie S1 PSE (Personal and Social Education); Gracemount High transition work P6, P7; Holyrood High CfE Science Outcomes; Craigholme School P6 \& P7 Religion, S2 Geography; Dunbar 
Grammar School Higher History. LTS are aiming to have the case studies on their website by the end of the year. These studies include both primary and secondary schools including those at Gracemount High and Craigholme which support the transitional agenda, an important value of information literacy.

The aim is now to further influence the Curriculum for Excellence with the support of leading partners but this is proving difficult as there are communication problems both within the Curriculum for Excellence team and LTS and the team's communication strategy with other agencies. However it is clear that we can play a major co-ordinating role and it is no exaggeration to say that we have stimulated unprecedented levels of activity in secondary education.

\section{The workplace agenda}

The other main current strand of our work, researching and promoting the use of information in the workplace is both an end in itself and will also contribute to the workplace/lifelong learning strands of the revised Framework. The foundation of this strand is an interview based study of the use of information in the workplace (Crawford and Irving, 2008b). A further new study (Crawford et al., 2008) concentrates specifically on the interviews carried out with civil servants and how the Scottish Government Information Service staff are implementing the findings. The overall outcomes suggest that there is scope for progress although probably more so in the public sector. Interviewees usually used only a narrow range of sources, mostly internally generated, and the main source of information used is always other people. Advanced internet searching was little used and there seems to be a training need here. Colleagues were found to be the main information source consulted and the public library was viewed by most interviewees as irrelevant for anything other than recreational purposes. Recommendations included the following:

- Contacts should be established with chambers of commerce, skills agencies and other organisations involved in workplace training

- Organizations' information polices which are largely implicit should be made explicit and should include accessing a wide range of information, of high quality, including sources outwith their organisation

- The viability of developing information literacy training programmes should be further researched

- Information literacy training programmes should initially target sympathetic organizations

- Advanced Internet training programmes should be offered to all workplace employees

- The provision of information literacy training programmes by public libraries should be investigated

- Developmental work should be undertaken with Adult Literacies agencies

- NHS contacts should be expanded to progress the health literacies agenda 
These recommendations have generated an agenda of meetings and action. We have held meetings with Glasgow Chamber of Commerce which, we hope, will lead to contacts with representatives of Small to Medium Sized Enterprises (SME's) to assess their information needs; we have met with CBI Scotland to recruit employers interested in developing information literacy as part of their CPD programmes. The employee focus is also being recognized and we have met the Everyday Skills Committee of the Scottish Trades Union Congress (STUC) with a view to having Information Literacy (IL) included in their repertoire of skills. Perhaps most promising of all is our contacts with Skills Development Scotland (SDS), a new skills body which is an amalgamation of learndirect Scotland, Careers Scotland and the training element of Scottish Enterprise.

This has led to the identification of a role for IL in careers advice both for the end user and also training for SDS staff. The key issue lying behind this activity is the need to have IL recognised as an essential part of the skills agenda. Government focus on skills has been around for several years but the LIS profession has noteworthily failed to recognise this important opportunity. In Scotland the key document is Skills for Scotland A Lifelong Skills Strategy (Scottish Government, 2007). It includes definitions for the skills referred to in the strategy. Included in the definition for Literacy is the interpreting and analysing of information, and how to reach informed decisions. Following a meeting with the Employability \& Skills Division, Lifelong Learning Directorate a 500 word piece on the relevance of information literacy and some case studies to demonstrate the relevance has been prepared for inclusion in the strategy update, which will be web based. Fortunately one of our most active project partners, Govan High School, (Blane, (2008), has developed a 'Future Skills' framework of some 70 skills in association with local employers and involving the pupils themselves. This is forming the basis of work with SDS and demonstrates a major policy role for IL. The Royal Society of Arts has now become involved and we hope it will sponsor a round table discussion at the Scottish Parliament on the role of IL in skills in 2009.

The lack of importance attached by interviewees to public libraries is an avenue to explore and this issue is being pursued with new partners: Dumfries and Galloway Library Services, the Mitchell Library in Glasgow and Inverclyde Libraries. All these services have major ICT and skills training programmes and adding information literacy training to training programmes seems an obvious step. A meeting was held with the Cultural Services Manager and the Senior ICT Officer based at the Ewart Library in Dumfries to discuss the work of the project and explore methods of mutual assistance. The library is part of the local Adult Literacy and Numeracy Partnership and provides resources across the library network for tutors and learners. They offer an expanding programme of tutor led computer training courses and workshops running in libraries to assist local communities. They also offer the British Computer Society e-Citizen package (2008) which includes information literacy although it does not identify it as such.

The Mitchell Library has a new Digital Learning team that has Learning Support Officers to look after the Glasgow REAL Learning Centres, learning portfolios, ITC and the employability agenda. Other items of interest included the partnership between Glasgow Libraries and the Chamber of Commerce and the breakfast sessions held at the Mitchell for Small to Medium Sized Enterprises (SMEs). We 
are exploring options with the newly appointed People's Network Librarian at Inverclyde to explore ways in which we can work together on Information Literacy and Public Library users.

In summer 2008 we were approached by a Consultancy, Timmus Limited to jointly tender for a Becta contract in our capacity as information literacy specialists to assist the Consultant in writing a report on Improving Digital Literacy in Schools (Pre School and key stage $1-4$ ). This involved identifying relevant literature, key players, issues to be addressed / questions to be answered including enablers and blockers, models, and recommendations to parents. Our bid was successful. As well as being a useful exercise in itself it made us aware that the educational research community is increasingly interested in critical thinking skills in relation to technology use - in other words, information literacy in an ICT context. Becta considers its work on digital information literacy to be closely aligned to media literacy (Ofcom, 2008?) and Ofcom's work. At a policy level while Ofcom is leading on Media literacy Becta leads the national drive to ensure the effective use of technology throughout learning.

The outcomes of the Becta review suggested the main difference between media and digital literacy is that the former deals with empowering people with critical thinking skills when consuming digital media in their leisure time, whereas the latter refers to critical thinking during task-based, formal activities using digital media. Earlier on in the Project we had a couple of meetings with Ofcom Scotland at one of which the definition of media literacy was discussed but these initial contacts lapsed. Thanks to the lessons learned from our consultancy work we are in contact again with Ofcom Scotland which has just re-established a Media Literacy Forum with lead partners Learning and Teaching Scotland, Skills Development Scotland, Scottish Screen and BBC Scotland. Ofcom Scotland plans some events for the future in which we will be involved. The meetings in Washington, including one with an executive board member of Association for a Media Literate America indicated a need to focus media literacy education on school age children so there is the germ of a policy issue here.

\section{Conclusion}

The work of the Project has shown that research and development work firmly based on the educational policy of a small country can both inform developments elsewhere and draw on practice throughout the world. Recent and planned developments show that it is necessary to advance well beyond the traditional information literacy paradigm as it is understood by librarians. When working with non library organisations it is necessary to realign the concept of information literacy to conform to the aims and objectives of the organisation targeted. The workplace interviews showed very different conceptions of information usage with the role of people being viewed as fundamental. Interviewees defined information literacy in terms of their own qualifications, training and work experience. Lloyd and Somerville's work with fire-fighters (2006) has already carried this approach even further by including smell and touch as information sources. 
It is clear that the skills agenda is becoming crucial in the promotion of information literacy and while this is welcome it is essential that information literacy should be identified as a discrete skill and not buried under such umbrella terms as soft skills and problem solving. The consultancy work with Becta has shown information and educational research drawing closer together and a link with media literacy emerging.

Earlier in the decade there was considerable interest in community development, lifelong learning and outreach activities (Hull 2000) but this seems to have lost momentum. By developing information literacy programmes in public libraries, perhaps working in conjunction with Adult literacies trainers, there may be scope to revive this agenda.

For those prepared to think outside the 'library box', the opportunities are considerable.

\section{References}

Blane, D. (2008) Core skills? What the ' $\mathrm{f}^{* * * \text { ' }}$ are they? Times Educational Supplement Scotland, 20/6.

British Computer Society (2008) e-Citizen. URL:

http://www.bcs.org/server.php?show=nav.5831 [accessed 06.11.08].

CfE (2008) Curriculum for Excellence - Aims, purposes and principles. URL: http://www.ltscotland.org.uk/curriculumforexcellence/index.asp [accessed 06.11.08].

Crawford, J. and Irving, C. (2007) Information literacy, the link between secondary and tertiary education project and its wider implications, Journal of Librarianship and Information Science, 39(1), 21-30.

Crawford, John and Irving, Christine, (2008a) Advocating information literacy, Information Scotland, 6, (4), 12-13. URL:

http://www.slainte.org.uk/publications/serials/infoscot/vol6(4)/vol6(4)article5.htm [accessed 28.11.08].

Crawford, J. and Irving, C. (2008b) Information literacy in the workplace: a qualitative exploratory study, Journal of Librarianship and Information Science, forthcoming.

Crawford, J. et al. (2008) The use of information by Scottish Government staff, Library + Information Update, December, 48-49.

Crawford, J. C. (2008) Making new friends: an information literacy trip to Washington, Journal of Information Literacy, 2(1). URL: http://ojs.lboro.ac.uk/ojs/index.php/JIL/article/view/ART-V2-I1-2008-1/137 [accessed 28.11.08].

Hull, B. (2000) Barriers to libraries as agents of lifelong learning. London Library and Information Commission research report 31. 
Lloyd, A. and Somerville, M. (2006) Working information, Journal of Workplace Learning, 18(3), 186-198.

McLelland, D. and Crawford, J. (2004) The Drumchapel Project: a study of ICT usage by school pupils and teachers in a secondary school in a deprived area of Glasgow, Journal of Librarianship and Information Science, 36(2), 55-67.

Ofcom (Office of communications) (2008?) What is media literacy? URL: http://www.ofcom.org.uk/advice/media_literacy/of med_lit/whatis/ [accessed 06.11.08].

Scottish Government (2007) Skills for Scotland A Lifelong Skills Strategy. Edinburgh: The Scottish Government. URL:

http://www.scotland.gov.uk/Publications/2007/09/06091114/0 [accessed 06.11.08].

Stubbings, R. (2008) Finns propel information literacy up the political agenda, Library + Information Update, 7(5), 24.

\section{Project website and blog}

Project website www.caledonian.ac.uk/ils/

Project blog http://caledonianblogs.net/information-literacy/

\section{Acknowledgements}

In preparing this text thanks to:

Ian McCracken, Learning Resources Manager, Govan High School; Janice Goldie and colleagues, Ewart Library Dumfries; Pamela Tulloch and colleagues, Mitchell Library; Sandra MacDougall and Sean McNamara, Inverclyde Libraries; Tabetha Newman, Timmus Limited and Andrea Shirley, Becta. 